CIHM

Microfiche Series (Monographs)
ICMH

Collection de microfiches (monographies)

Sanadian Institute for Historical Microreproductions / Institut canadien de microreproductions historiques
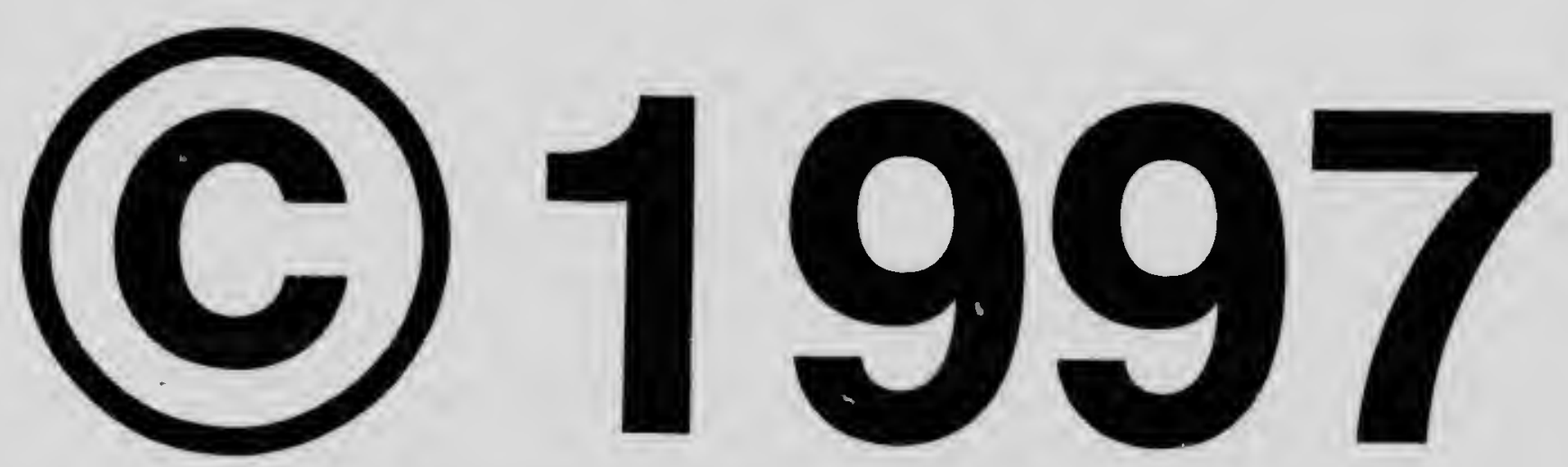


\section{Technical and Bibliographic Notes / Notes techniques et bibliographiques}

The Instltute has attempted to obtain the best orlginal copy avallable for filming. Features of this copy which may be blbliographlcally unique, which may alter any of the Images In the reproduction, or whlch may slgniflcantly change the usual method of filming are checked below.

\section{Coloured covers $/$}

Couverture de couleur

\section{Covers damaged /}

Couverture endommagée

Covers restored and/or laminated/

Couverture restaurée et/ou pelliculée

Cover title missing / Le titre de couverture manque

Coloured maps / Cartes géographiques en couleur

Coloured ink (i.e. other than blue or black) /

Encre de couleur (i.e. autre que bleue ou noire)

Coloured plates and/or illustrations /

Planches et/ou illustrations en couleur

Bound with other material /

Relié avec d'autres documents

Only edition available /

Seule édition disponible

Tight binding may cause shadows or distortion along interior margin / La reliure serrée peut causer de l'ombre ou de la distorsion le long de la marge intérieure.

Blank leaves added during restorations may appear within the text. Whenever possible, these have been omitted from filming / II se peut que certaines pages blanches ajoutées lors d'une restauration apparaissen! dans le texte, mais, lorsque cela était possible, ces pages n'ont pas été filmées.

Additional comments /

Commentaires supplémentaires:
L'Instltut a microfllmé le mellleur exemplaire qu'il lul a été possible de se procurer. Les détails de cet exemplaire qui sont peut-être uniques du point de vue bibliographique, qul peuvent modifier $7 e$ Image reproduite, ou qul peuvent exiger une modification dans la méthode normale de filmage sont indiqués ci-dessous.

\section{Coloured pages / Pages do couleur}

\section{Pages damaged / Pages endommagées}

Pages restored and/or laminated/

Pages restaurées et/ou pelliculées

Pages discoloured, stained or foxed /

Pages décolorées, tachetées ou piquées

Pages detached / Pages détachées

\section{Showthrough / Transparence}

Quality of print varies /

Qualité inégale de l'impression

Includes supplementary material /

Comprend du matériel supplémentaire

Pages wholly or partially obscured by errata slips, tissues, etc., have been refilmed to ensure the best possible image / Les pages totalement ou partiellement obscurcies par un feuillet d'errata, une pelure, etc., ont été filmées à nouveau de façon à obtenir la meilleure image possible.

Opposing pages with varying colouration or discolourations are filmed twice to ensure the best possible image / Les pages s'opposant ayant des colorations variables ou des décolorations sont filmées deux fois afin d'obtenir la meilleure image possible.

This item is filmed at the reduction ratio checked below I

Ce document est filmó au taux de réduction indiques ci-dessous.

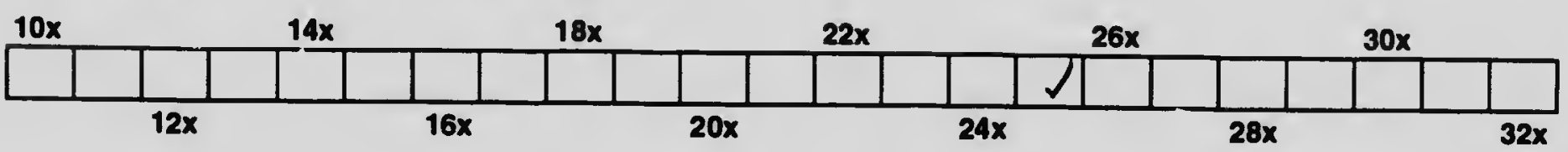


The copy filmed here has been repreduced thanks to the generoslity of:

\section{Library \\ Agriculiure Canada}

The Imeges appearing here ere the best quellty posslble consldering the condition and leglbillty of the orlginel copy end In keepling with the fllming contrect speclflcatlons.

Originol coples In printed peper covers ere fllmed beginning with the front cover and ending on the lest pege with a printed or Illustrated Impres. slon, or the beck cover when epproprlate. All other orlginal coples ere filmed beginning on the flrst fege with o printed or lllustreted Impres. slon, end ending on the last page with e printed or lliustrated Impression.

The lest recorded freme on each microflche shell contaln the symbel $\rightarrow$ Imeening "CON. TINUED"), or the symbol $\nabla$ (meening "END"). whichover applles.

Meps, plotes, charts, otc., mey be filmed ot different reductlon retlos. Those too large to be entirely Included In one exposure are fllmed beginning In the upper left hend corner, left to right and top to bottom, as many frames as required. The following dlagrams lliustrate the mothod:
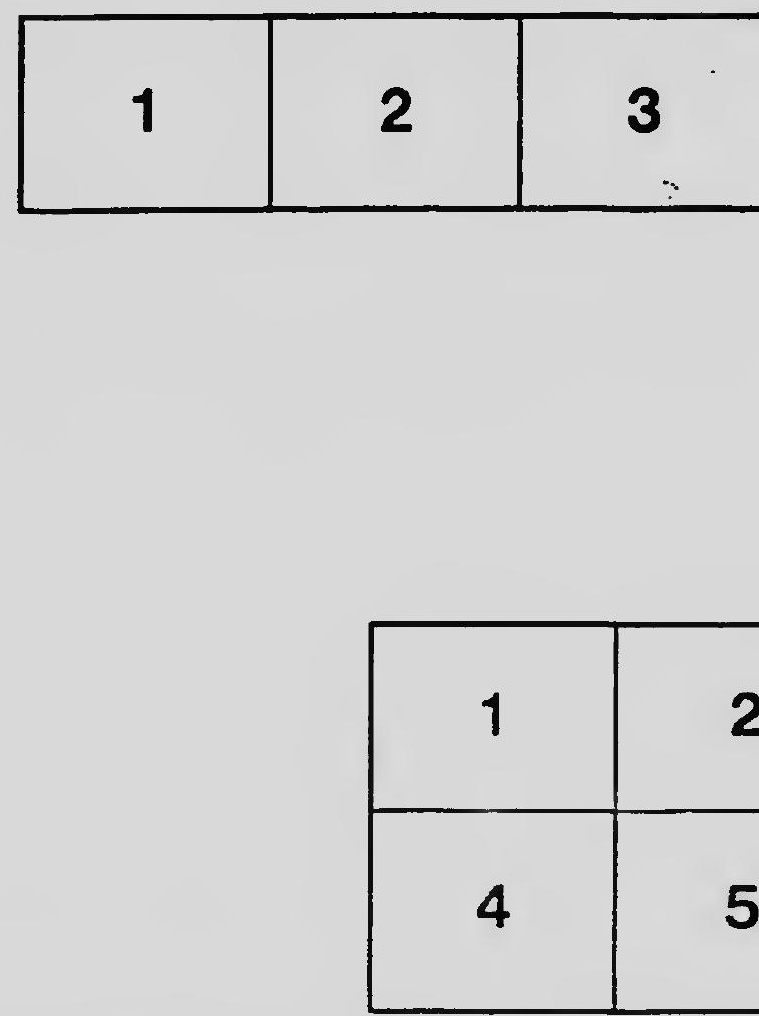
L'exemplaire filme fut reprodult gráce ta gónórosité de:

Bibliothique

Agriculture Canada

Les Images sulvantes ont bté reprodultes avec lo plus grand soln, compte tenu de la condition et de la nertete de l'exemplalre fllmó, et en conformite avec les conditlons du contrat de fllmage.

Les exemplalres orlginaux dont la couverture en papler est Imprimbe sont fllmb́s en commençant par le premler plat et en terminant solt par la dernilere page qul comporte une empreinte d'Impression ou d'illustration, solt par le second plat, selon le cas. Tous les autres exemplaires orlginaux sont fllmds en commençant par la premlàre page qui comporte une emprelnte d'Impression ou d'illustration et en terminant par la dernlare page qul comporte une telle emprelnte.

Un des symboles sulvents apparaitre sur le dernidre Image de cheque microfiche, selon le cas: le symbole $\rightarrow$ slonifle "A SUIVRE", le symbole $\nabla$ slgnifle "FIN".

Les cartes, planches, tableaux, etc., peuvent stre flimb́s des taux de réduction diffórents. Lorsque le document est trop grand pour etre reprodult en un seul cllchb, II est fllmb a partir de l'angle supbrieur gauche, de gauche didrolte, ot de haut on bas, en prenant le nombre d'Images nd́cessalre. Les dlagrammes sulvants Illustrent la máthode.
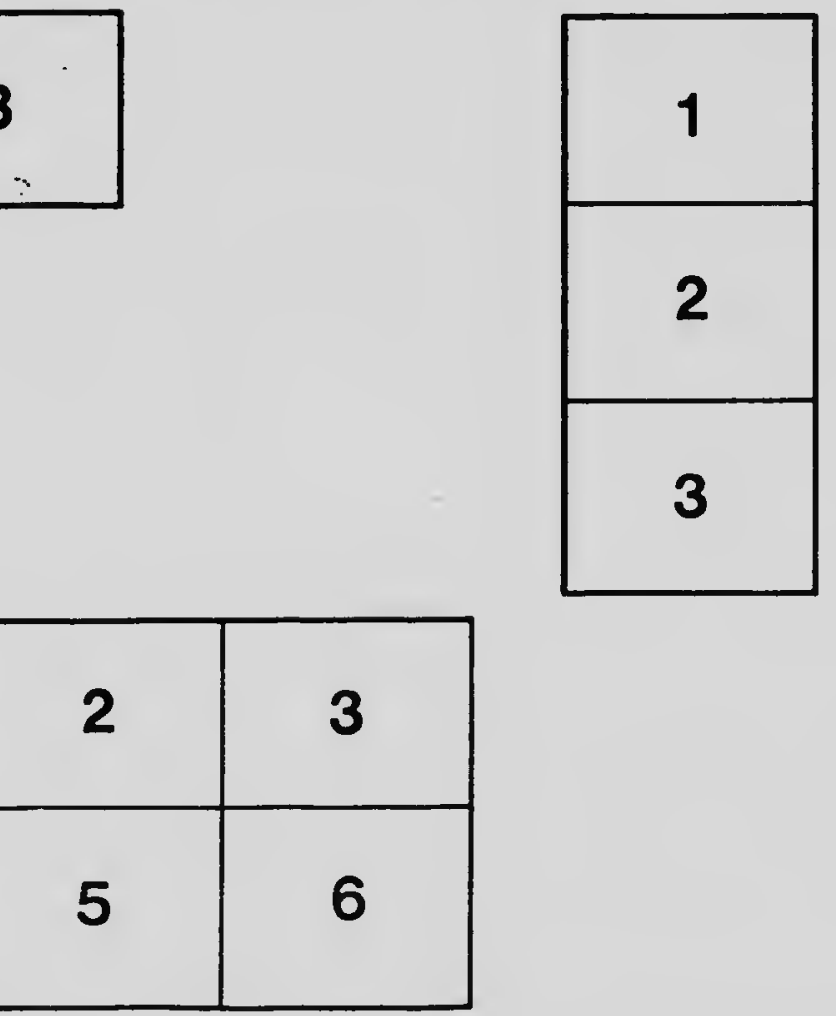
(ANSI and ISO TEST CHART NO. 2)
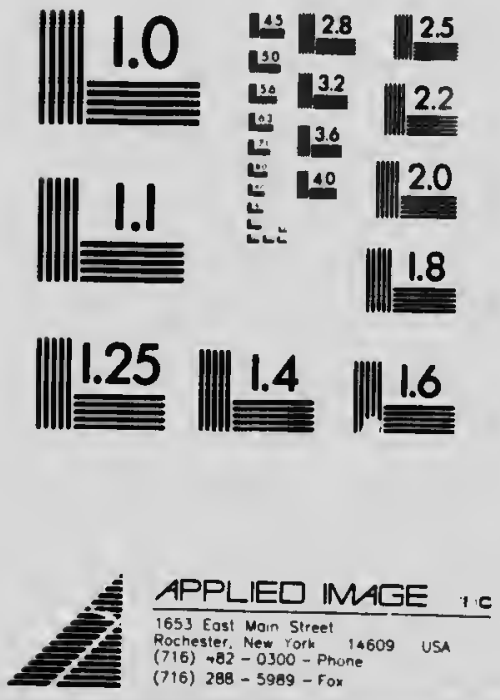


\author{
CIRCULAK No. 15 \\ 1)O.IINION OH' ('A.T.11).1 \\ DOMINION EXPERIMENTAL FARMS \\ J. H. GRISDALE, B.Agr., \\ Director. \\ W. T. MACOUN, \\ Dominion Horticulturlat.
}

\title{
Selection and Wintering of Biennial Vegetables for Seed
}

\author{
B. IV. T. I/ Irulex.
}

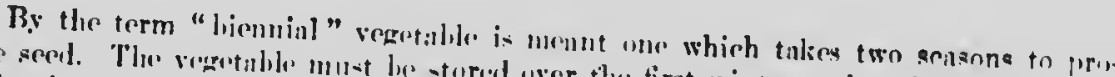

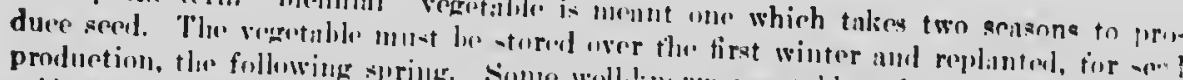

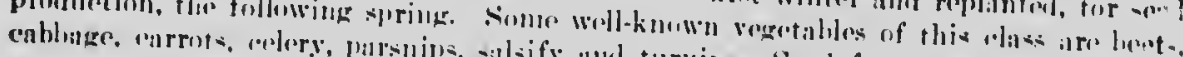
grown in Canardal if ther

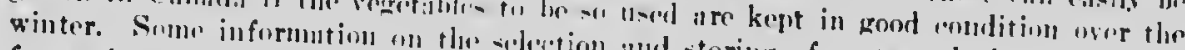

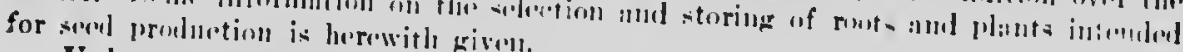

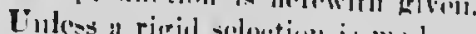

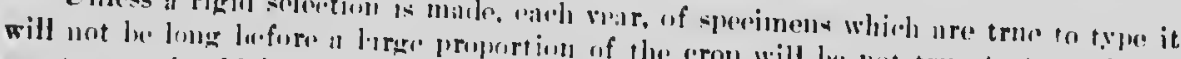

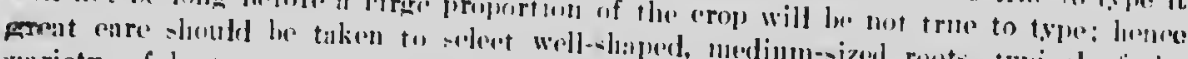

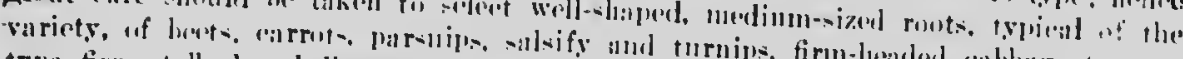

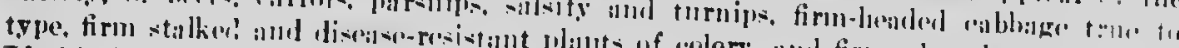

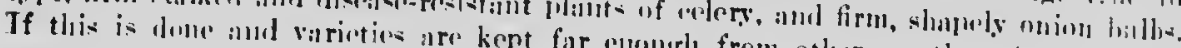

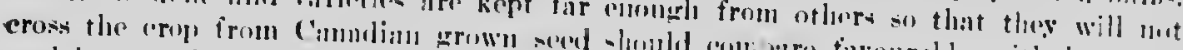

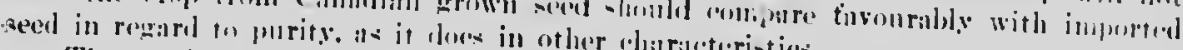

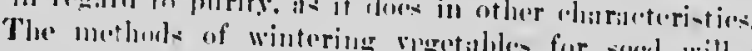

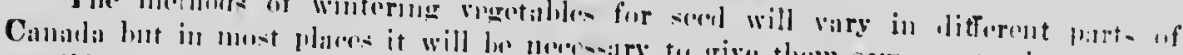

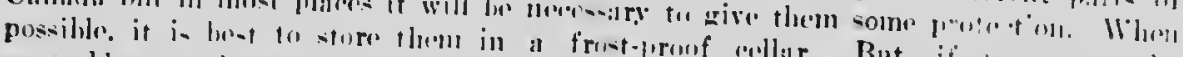

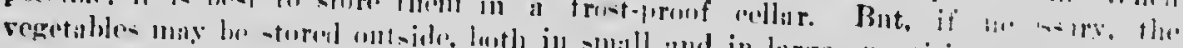

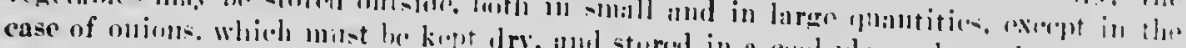
or no frost.

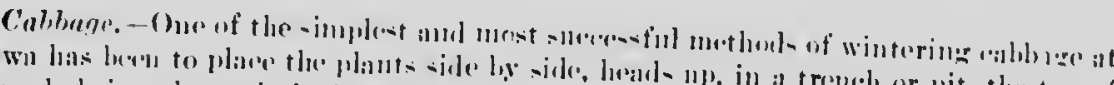

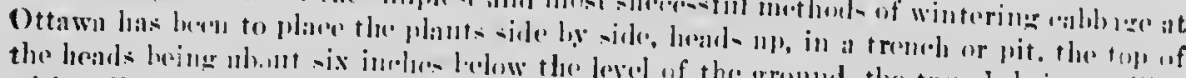

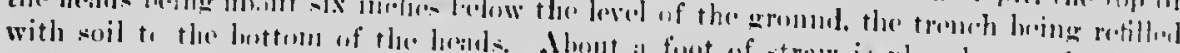

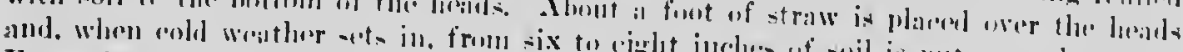

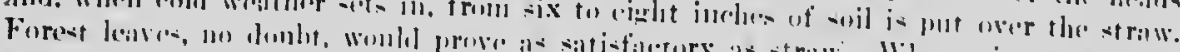

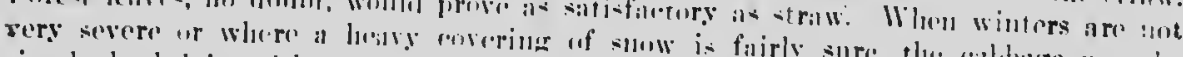

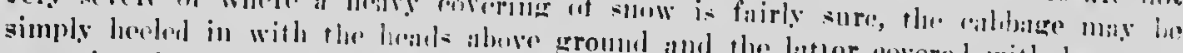

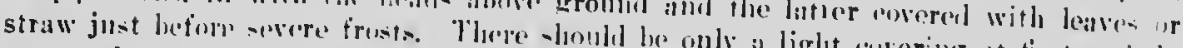

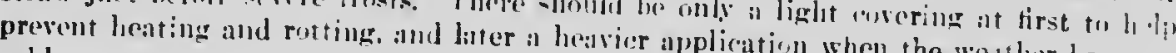
cold. 


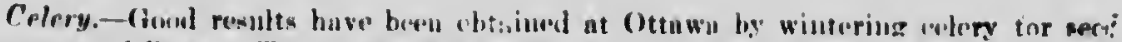

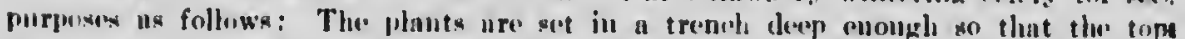

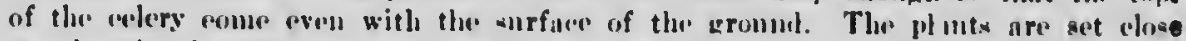

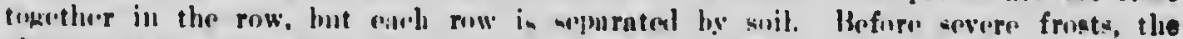

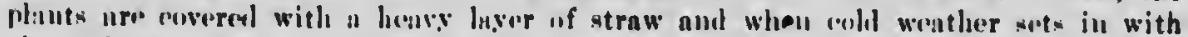

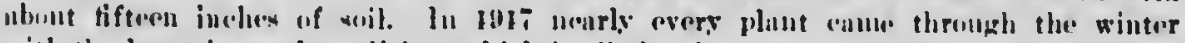

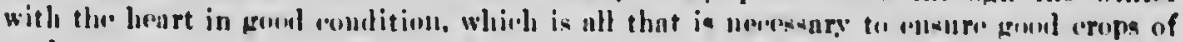
\$14.4I.

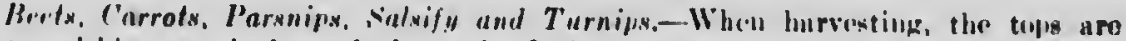
cut to within two inehes of the end of the spereimen, thus lenving the central shoot. This is better thull ('nttiug off the leaves close to tho root. Tha pit in which

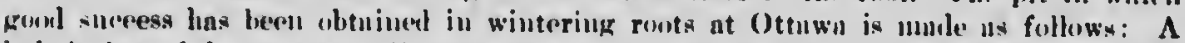

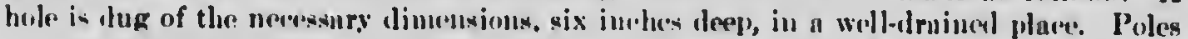

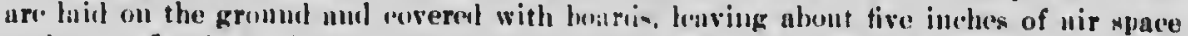

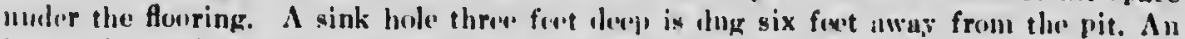
iuverforl trongh-shuped pipe eonnertiug this hole wit! the uir spuec under the pif gives a "humce for air circulation and drniunge of any water that might sonk in. The rooss are put in bags to sepurate them better, though this is not ulwuys necessury, and piled tlire tiors high. rumning to a penk. A penked roof of bunds is put over the pit, high enomgh nlove the bags to allow ubout fifteen imehes of straw to be pueked in between; over the roof is put a light cont of struw and then fifton inehes of soil. $A$ vent hole nime inches square is left in the ceutre of the rouf. Before hard frost the sink hole is filled with straw and covered with burals und twelve inehes of soil. The evoring with soil should be deferred until cold weather sets in to nvoid daurer of henting. Ind during the winter the temperature insile the pits shoull bu taken if the pits are large. In many plures parsnips Im. be left in the ground over winter and transplanted in the spring when bettor results will be whtnined thun if pitted, as thry ire very lardy. 


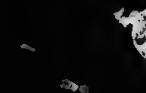

$\because \quad:$ 


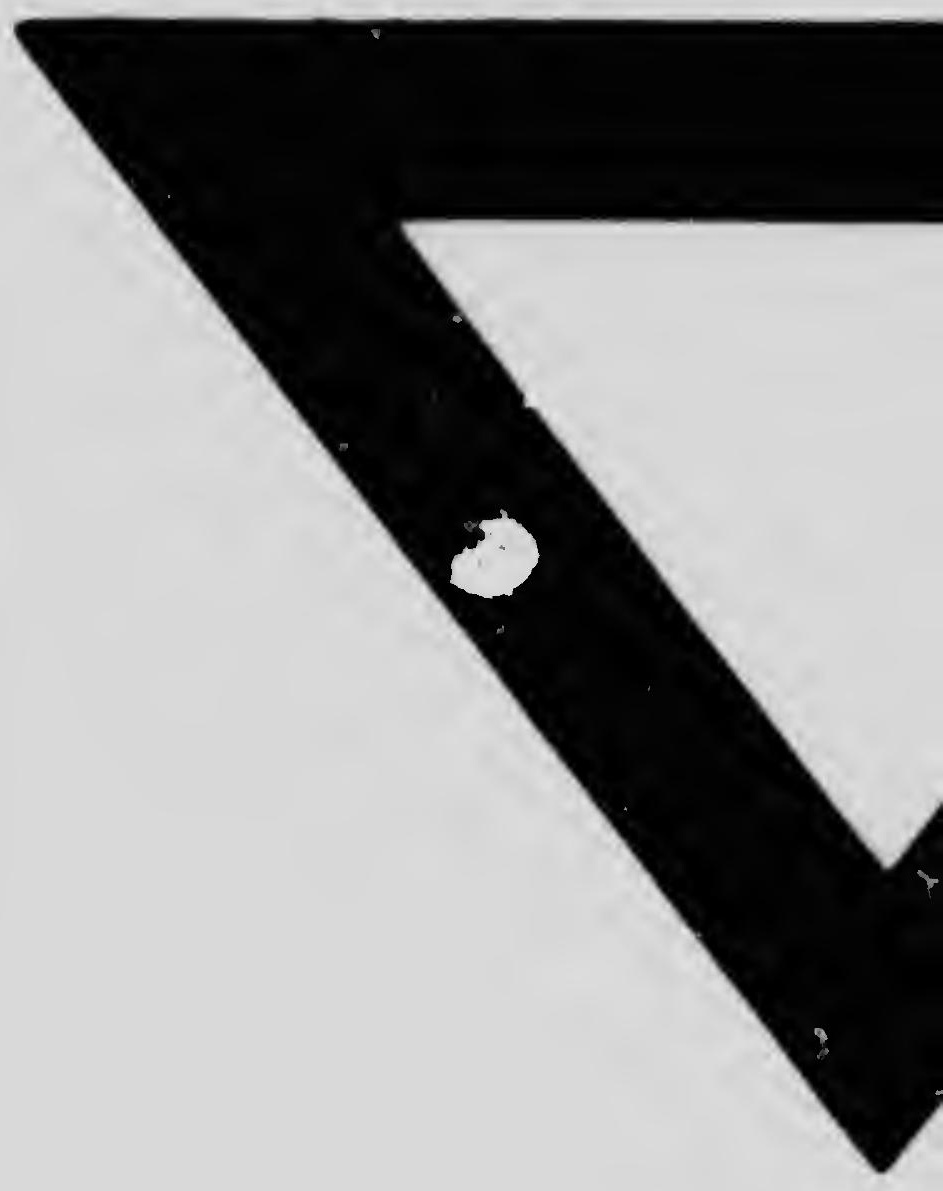




$$
7
$$

